\title{
Metode Penetapan Tarif Pajak Penghasilan Yang Berkeadilan ${ }^{1}$ Westi Riani; ${ }^{2}$ Sigit Haryadi

\author{
${ }^{1}$ Fakultas Ekonomi, Universitas Islam Bandung, Jl. Tamansari No. 1 Bandung 40116 \\ ${ }^{2}$ Institut Teknologi Bandung, Jl. Ganesha No. 10 Bandung 40132 email : \\ ${ }^{1}$ Westiriani@yahoo.com; ${ }^{2}$ sigit@stei.itb.ac.id
}

\begin{abstract}
Abstrak. Keadilan (a'dl) dalam al-Quran memiliki aspek dan objek yang beragam. Keadilan (a'dl) bisa bermakna sama atau simbang. Dalam kehidupan bernegara, makna keadilan berarti memperlakukan dan memberikan sesuatu hal sebagai kewajiban, baik terhadap diri sendiri, sesama manusia maupun terhadap Tuhan. Salah satu produk hukum yang ditetapkan dengan mengedepankan amanat keadilan adalah undang-undang tentang pajak. Keadilan dalam pemungutan pajak biasanya diukur dengan melihat perbandingan antara jumlah pajak yang dibayar dan kemampuan membayar (abiity to pay) pajak yang diukur dengan tingkat penghasilan wajib pajak. Pada umumnya dirasakan adil bila orang yang kemampan membayar pajak tinggi dikenai pajak yang tinggi pula relatif terhadap orang yang penghasilannya atau kemampuannya membayar pajak rendah. Dalam praktek di Indonesia, saat ini penetapan tarif pajak penghasilan (PPh 21) berkisar antara 5\%30\%, dengan tingkat keadilan tarif pajak (Fairness) sekitar $60 \%$ yang menunjukan bahwa baru sekitar 60 $\%$ penduduk yang telah membayar pajak dengan benar sehingga mereka harus membayar pajak penghasilan dengan tarif yang jauh lebih tinggi dibandingkan bila seluruh penduduk telah membayar pajak dengan benar. Pada makalah ini diusulkan suatu formula untuk menghitung tarif pajak yang berasas keadilan, Penetapan tarif pajak penghasilan dengan menggunakan formula "Tarif Pajak Berkeadilan" akan menghasilkan tarif pajak yang "adil” bagi setiap kelompok pendapatan..Besaran tarif pajak berkeadilan untuk setiap kelompok pendapatan juga dipengaruhi oleh Fairness atau tingkat keadilan tarif pajak yang menunjukkan persentase jumlah penduduk yang membayar pajak penghasilan dengan benar. Semakin tinggi Fairness, tarif pajak berkeadilan untuk tiap tingkat pendapatan akan semakin turun.
\end{abstract}

Kata Kunci: Keadilan; tarif pajak; formula baru

Catatan: Sudah dibuat suatu "Kalkulator Internet" terkait makalah ini, sehingga anda dapat melakukan perhitungan dengan mudah, yaitu di alamat:

http://sigitharyadi.net/id/multidicipline/income-tax-rates-calculator-id/

\section{Pendahuluan}

1. Kata 'adl di dalam al-Quran memiliki aspek dan objek yang beragam. Keragaman tersebut mengakibatkan keragaman makna 'adl (keadilan). Setidaknya ada empat makna keadilan. Pertama, 'adl dalam arti "sama". Pengertian ini yang paling 
| Westi Riani, et al.

banyak terdapat di dalam al-Quran, antara lain pada S. an-Nisa' (4): 3, 58 dan 129, S. asy-Syura (42): 15, S. Al-Ma'idah (5): 8, S. An-Nahl (16): 76, 90, dan S. AlHujurat (49): 9. Kata 'adl dengan arti sama (persamaan) pada ayat-ayat tersebut yang dimaksud adalah persamaan dalam hak. Kedua, 'adl dalam arti “seimbang”.

Pengertian ini ditemukan di dalam S. al-Ma'idah (5): 95 dan S. al-Infithar (82): 7. Ketiga, 'adl dalam arti "perhatian terhadap hak individu dan memberikan hak itu kepada setiap pemiliknya". Keempat, 'adl dalam arti yang dinisbahkan kepada Allah. 'Adl di sini berarti memelihara kewajaran atas berlanjutnya eksistensi, tidak mencegah kelanjutan eksistensi dan perolehan rahmat saat terdapat banyak kemungkinan untuk itu.

2. Dalam kehidupan bernegara, kata adil (keadilan) terdapat dalam sila kelima yaitu Keadilan Sosial Bagi Seluruh Rakyat Indonesia. Keadilan (adil) berarti memperlakukan dan memberikan sesuatu hal sebagai kewajiban, baik terhadap diri sendiri, sesama manusia maupun terhadap Tuhan. Perbuatan adil menyebabkan sesorang memperoleh apa yang menjadi haknya, dan dasar dari hak ini adalah pengakuan kemanusiaan yang mendorong perbuatan manusia untuk memperlakukan sesama sebagaimana mestinya. Penegakan keadilan akan membuat kehidupan manusia Indonesia baik selaku pribadi, masyarakat maupun warga negara, menjadi aman, tenteram dan sejahtera. Sila Keadilan Sosial Bagi Seluruh Rakyat Indonesia mengandung makna bahwa setiap peraturan hukum, baik Undang-undang maupun putusan pengadilan mencerminkan semangat keadilan.

3. Salah satu produk hukum yang ditetapkan dengan mengedepankan amanat keadilan adalah undang-undang tentang pajak. Pajak merupakan iuran rakyat kepada negara berdasarkan undang-undang, sehingga dapat dipaksakan, dengan tidak mendapat balas jasa secara langsung. Berdasarkan UU KUP Nomor 28 Tahun 2007, pasal 1, ayat 1, pengertian Pajak adalah kontribusi wajib kepada negara yang terutang oleh orang pribadi atau badan yang bersifat memaksa berdasarkan undang-undang, dengan tidak mendapatkan imbalan secara langsung dan digunakan untuk keperluan negara bagi sebesar-besarnya kemakmuran rakyat. Keadilan dalam pemungutan pajak biasanya diukur dengan melihat perbandingan antara jumlah pajak yang dibayar dan kemampuan membayar (abiity to pay) pajak yang diukur dengan tingkat penghasilan wajib pajak. Pada umumnya dirasakan adil bila orang yang kemampan membayar pajak tinggi dikenai atau dipungut pajak yang tingi pula reltif terhadap orang yang penghasilannya atau kemampuannya membayar pajak rendah.

(Suparmoko,2000:348)

\section{Tinjauan Pustaka :.Pasal-Pasal penting dalam Undang-undang Pajak Penghasilan}

\subsection{Pasal 4 ayat 2 : pajak final}

Penghasilan di bawah ini dapat dikenai pajak bersifat final: 
a. Penghasilan berupa bunga deposito dan tabungan lainnya, bunga obligasi dan surat utang negara, dan bunga simpanan yang dibayarkan oleh koperasi kepada anggota koperasi orang pribadi;

b. Penghasilan berupa hadiah undian;

c. Penghasilan dari transaksi saham dan sekuritas lainnya, transaksi derivatif yang diperdagangkan di bursa, dan transaksi penjualan saham atau pengalihan penyertaan modal pada perusahaan pasangannya yang dterima perusahaan modal ventura;

d. Penghasilan dari transaksi pengalihan harta berupa tanah dan/atau bangunan, usaha jasa konstruksi, usaha real estate, dan persewaan tanah dan/bangunan; dan

e. Penghasilan tertentu lainnya, yang diatur dengan atau berdasarkan Peraturan Pemerintah.

\subsection{Pasal 7 ayat 1 : penghasilan tidak kena pajak}

Penghasilan Tidak Kena Pajak per tahun diberikan paling sedikit sebesar:

a. Rp15.840.000,00 untuk diri wajib pajak orang pribadi;

b. Rp1.320.000,00 tambahan untuk wajib pajak yang kawin;

c. Rp15.840.000,00 tambahan untuk seorang istri yang penghasilannya digabung dengan penghasilan suami sebagaimana dimaksud dalam Pasal 8 ayat 1; dan

d. Rp1.320.000,00 tambahan untuk setiap anggota keluarga sedarah dan keluarga semenda dalam garis keturunan lurus serta anak angkat, yang menjadi tanggungan sepenuhnya, paling banyak 3 (tiga) orang untuk setiap keluarga.

Untuk masa berlaku mulai pada 1 Januari 2013 terjadi perubahan ketentuan PTKP yang tertuang dalam Pasal 1 Peraturan Menteri Keuangan Republik Indonesia Nomor 162/PMK.011/2012 Tentang Penyesuaian Besarnya Penghasilan Tidak Kena Pajak dalam mengubah angka-angka berikut:

- Angka pada huruf a dan c, menjadi Rp24.300.000,00

- Angka pada huruf b dan d, menjadi Rp2.025.000,00

Besaran PTKP mulai berlaku sebagai dasar perhitungan PPh orang pribadi untuk tahun pajak 2015 sejak tanggal 1 Januari 2015.

Batasan PTKP 2015, untuk:

- Diri Wajib Pajak Orang Pribadi sebesar Rp 36.000.000;

- Tambahan bagi Wajib Pajak Kawin Rp 3.000.000;

- Tambahan untuk istri yang penghasilannya digabung dengan suami Rp36.000.000; dan

- Tambahan untuk setiap tanggungan Rp. 3.000.000.

Perubahan terbaru besaran PTKP yang berlaku per 1 Januari 2016 adalah:

- Diri Wajib Pajak Orang Pribadi sebesar Rp 54.000.000;

- Tambahan bagi Wajib Pajak Kawin Rp 4.500.000;

- Tambahan untuk istri yang penghasilannya digabung dengan suami Rp354.000.000; dan

- Tambahan untuk setiap tanggungan Rp. 4.500.000.

\subsection{Pasal 14 ayat 2 : norma penghitungan penghasilan neto}

Wajib Pajak orang pribadi yang melakukan kegiatan usaha atau pekerjaan bebas yang peredaran brutonya dalam 1 (satu) tahun kurang dari Rp4.800.000.000,00 boleh menghitung penghasilan neto dengan menggunakan Norma Penghitungan Penghasilan Neto sebagaimana dimaksud pada ayat 1 , dengan syarat memberitahukan kepada Direktur Jenderal Pajak dalam jangka waktu 3 bulan pertama dari tahun pajak yang bersangkutan. 


\subsection{Pasal 17 ayat 1: tarif pajak}

Tarif pajak yang diterapkan atas Penghasilan Kena Pajak bagi:

a.Wajib Pajak orang pribadi dalam negeri adalah sebagai berikut:

- Lapisan Penghasilan Kena Pajak Tarif Pajak

- Sampai dengan Rp50.000.000,00 5\%

- Di atas Rp50.000.000,00 s.d. Rp250.000.000,00 15\%

- Di atas Rp250.000.000,00 s.d. Rp500.000.000,00 25\%

- Di atas Rp500.000.000,00 30\%

b. Wajib Pajak badan usaha dalam negeri dan bentuk usaha tetap adalah sebesar $28 \%$.

\subsection{Pasal 17 ayat 2a : tarif pajak badan usaha diturunkan}

Tarif sebagaimana dimaksud pada ayat 1 huruf $b$ menjadi $25 \%$ yang mulai berlaku sejak tahun pajak 2010.

Ada lagi, dalam Pasal 3 ayat 1 pada Peraturan Pemerintah Nomor 46 Tahun 2013 (biasa disebut PP 46) yaitu pajak penghasilan bersifat final sebesar 1\% dari peredaran bruto (omset/penjualan kotor) yang tidak melebihi Rp4,8Milyar, bagi orang pribadi dan badan usaha (kecuali BUT).

\subsection{Pasal 17 ayat $2 \mathrm{~b}$ : tarif pajak perseroan terbuka}

Wajib Pajak badan usaha dalam negeri yang berbentuk perseroan terbuka yang paling sedikit $40 \%$ dari jumlah keseluruhan saham yang disetor diperdagangkan di bursa efek di Indonesia dan memenuhi persyaratan tertentu lainnya dapat memperoleh tarif sebesar 5\% lebih rendah daripada tarif sebagaimana dimaksud pada ayat 1 huruf $\mathrm{b}$ dan ayat 2 a yang diatur dengan atau berdasarkan Peraturan Pemerintah.

\subsection{Pasal 17 ayat $2 \mathrm{c}$ : tarif pajak dividen orang pribadi}

Tarif yang dikenakan atas penghasilan berupa dividen yang dibagikan kepada Wajib Pajak orang pribadi dalam negeri adalah paling tinggi sebesar $10 \%$ dan bersifat final.

\subsection{Pasal 21 ayat 5 : tarif $P P h 21$}

Tarif pemotongan atas penghasilan sebagaimana dimaksud pada ayat 1 adalah tarif pajak sebagaimana dimaksud dalam Pasa 17 ayat 1 huruf a, kecuali ditetapkan lain dengan Peraturan Pemerintah.

\subsection{Pasal 22 ayat 1 : penyerahan barang, impor, dan kegiatan lain, serta barang sangat mewah}

Menteri Keuangan dapat menetapkan:

a. Bendahara pemerintah untuk memungut Pajak sehubungan dengan pembayaran atas penyerahan barang;

b. Badan-badan tertentu untuk memungut pajak dari Wajib Pajak yang melakukan kegiatan di bidang impor atau kegiatan usaha di bidang lain; dan

c. Wajib Pajak badan tertentu untuk memungut pajak dari pembeli atas penjualan barang yang tergolong sangat mewah.

\subsection{Pasal 23 ayat 1 : objek dan tarif pajak PPh 23}

Atas penghasilan tersebut di bawah ini dengan nama dan dalam bentuk apa pun yang dibayarkan, disediakan untuk dibayarkan, atau telah jatuh tempo pembayarannya 
oleh badan pemerintah, subjek pajak dalam negeri, penyelenggara kegiatan, bentuk usaha tetap, atau perwakilan perusahaan luar negeri lainnya kepada Wajib Pajak dalam negeri atau bentuk usaha tetap, dipotong pajak oleh pihak yang wajib membayarkan: a. Sebesar $15 \%$ dari jumlah bruto atas:

- Dividen sebagaimana dimaksud dalam Pasal 4 ayat 1 huruf g;

- Bunga sebagaimana dimaksud dalam Pasal 4 ayat 1 huruf f; • Royalti;

- Hadiah, penghargaan, bonus, dan sejenisnya selain yang telah dipotong Pajak

Penghasilan sebagaimana dimaksud dalam Pasal 21 ayat 1 huruf e;

b. Sebesar $2 \%$ dari jumlah bruto atas:

- Sewa dan penghasilan lain sehubungan dengan penggunaan harta, kecuali sewa dan penghasilan lain sehubungan dengan harta yang telah dikenai Pajak Penghasilan sebagaimana dimaksud dalam Pasal 4 ayat 2; dan

- Imbalan sehubungan dengan jasa teknik, jasa manajemen, jasa konstruksi, jasa konsultan, dan jasa lain selain jasa yang telah dipotong Pajak Penghasilan sebagaimana dimaksud dalam Pasal 21.

\subsection{Pasal 24 ayat 1 : kredit pajak luar negeri}

Pajak yang dibayar atau terutang di luar negeri atas penghasilan dari luar negeri yang diterima atau diperoleh Wajiib Pajak dalam negeri boleh dikreditkan terhadap pajak yang terutang berdasarkan Undang-undang ini dalam tahun pajak yang sama.

\subsection{Pasal 25 ayat 1 : angsuran pajak}

Besarnya angsuran pajak dalam tahun berjalan yang harus dibayar sendiri oleh Wajib Pajak untuk setiap bulan adalah sebesar Pajak Penghasilan yang terutang menurut Surat Pemberitahuan Tahunan Pajak Penghasilan tahun pajak yang lalu dikurangi dengan: a. Pajak Penghasilan yang dipotong sebagaimana dimaksud dalam Pasal 21 dan Pasal 23 serta Pajak Penghasilan yang dipungut sebagaimana dimaksud dalam Pasal 22; dan

b. Pajak Penghasilan yang dibayar atau terutang di luar negeri yang boleh dikreditkan sebagaimana dimaksud dalam Pasal 24, dibagi 12atau banyaknya bulan dalam bagian tahun pajak.

\subsection{Pasal 26 ayat 1, 2, 2a, dan 4 : pajak final atas penghasilan pihak asing di dalam negeri}

Ayat 1: Atas penghasilan tersebut di bawah ini, dengan nama dan dalam bentuk apa pun, yang dibayarkan, disediakan untuk dibayarkan, atau telah jatuh tempo pembayarannya oleh badan pemerintah, subjek pajak dalam negeri, penyelenggara kegiatan, bentuk usaha tetap, atau perwakilan perusahaan luar negeri lainnya kepada Wajib Pajak luar negeri selain bentuk usaha tetap di Indonesia dipotong pajak sebesar $20 \%$ dari jumlah bruto oleh pihak yang wajib membayarkan: a. Dividen;

b. Bunga termasuk premium, diskonto, dan imbalan sehubungan dengan jaminan pengembalian utang;

c. Royalti, sewa, dan penghasilan lain sehubungan dengan penggunaan harta;

d. Imbalan sehubungan dengan jasa, pekerjaan, dan kegiatan;

e. Hadiah dan penghargaan;

f. Pensiun dan pembayaran berkala lainnya;

g. Premi swap dan transaksi lindung nilai lainnya dan/atau

h. Keuntungan karena pembebasan utang. 
Ayat 2: Atas penghasilan dari penjualan atau pengalihan harta di Indonesia, kecuali yang diatur dalam Pasal 4 ayat 2, yang diterima atau diperoleh Wajib Pajak luar negeri selain bentuk usaha tetap di Indonesia, dan premi asuransi yang dibayarkan kepada perusahaan asuransi luar negeri dipotong pajak 20\% dari perkiraan penghasilan neto.

Ayat 2a: Atas penghasilan dari penjualan atau pengalihan saham sebagaimana dimaksud dalam Pasal 18 ayat 3c dipotong pajak sebesar $20 \%$ dari perkiraan penghasilan neto.

Ayat 4: Penghasilan Kena Pajak sesudah dikurangi pajak dari suatu bentuk usaha tetap di Indonesia dikenai pajak sebesar 20\%, kecuali penghasilan tersebut ditanamkan kembali di Indonesia, yang ketentuannya diatur lebih lanjut dengan atau berdasarkan Peraturan Menteri Keuangan.

Ayat 5: Pemotongan pajak sebagaimana dimaksud pada ayat 1, 2, 2a, dan 4 bersifat final, kecuali:

a. Pemotongan atas penghasilan sebagaimana dimaksud dalam Pasal 5 ayat 1 huruf $\mathrm{b}$ dan huruf c; dan

b. Pemotongan atas penghasilan yang diterima atau diperoleh orang pribadi atau badan luar negeri yang berubah status menjadi Wajib Pajak dalam negeri atau bentuk usaha tetap.

\subsection{Pasal 28 ayat 1 : kredit pajak atas pajak terutang}

Bagi Wajib Pajak dalam negeri dan bentuk usaha tetap, pajak yang terutang dkurangi dengan kredit pajak untuk tahun pajak yang bersangkutan, berupa:

a. Pemotongan pajak atas penghasilan dari pekerjaan, jasa, dan kegiatan sebagaimana dimaksud dalam Pasal 21;

b. Pemungutan pajak atas penghasilan dari kegiatan di bidang impor atau kegiatan usaha di bidang lain sebagaimana dimaksud dalam Pasal 22;

c. Pemotongan pajak atas penghasilan berupa dividen, bunga, royalti, sewa, hadiah, dan penghargaan, dan imbalan jasa sebagaimana dimaksud dalam Pasal 23;

d. Pajak yang dibayar atau terutang atas penghasilan dari luar negeri yang boleh dikreditkan sebagaimana dimaksud dalam Pasal 24;

e. Pembayaran yang dilakukan oleh Wajib Pajak sendiri sebagaimana dimaksud dalam

Pasal 25;

f. Pemotongan pajak atas penghasilan sebagaimana dimaksud dalam Pasal 26 ayat 5.

\subsection{Pasal 28A : pajak lebih bayar}

Apabila pajak yang terutang untuk satu tahun pajak ternyata lebih kecil dari jumlah kredit pajak sebagaimana dimaksud dalam Pasal 28 ayat 1, maka setelah dilakukan pemeriksaan, kelebihan pembayaran pajak dikembalikan setelah diperhitungkan dengan utang pajak berikut sanksi-sanksinya.

\subsection{Pasal 29 : pajak kurang bayar}

Apabila pajak yang terutang untuk suatu tahun Pajak ternyata lebih besar daripada kredit pajak sebagaimana dimaksud dalam Pasal 28 ayat 1, kekurangan pembayaran pajak yang terutang harus dilunasi sebelum Surat Pemberitahuan Tahunan Pajak Penghasilan disampaikan. 


\subsection{Pasal 31E : keringanan tarif pajak}

Wajib Pajak badan dalam negeri dengan peredaran bruto sampai dengan Rp50.000.000.000,00 mendapat fasilitas berupa pengurangan tarif sebesar 50\% dari tarif sebagaimana dimaksud dalam Pasal 17 ayat 1 huruf $b$ dan ayat 2 a yang dikenakan atas Penghasilan Kena Pajak dari bagian peredaran bruto sampai dengan Rp4.800.000.000,00.

\section{Pembahasan : Metode Penetapan Tarif Pajak Penghasilan Yang} Berkeadilan

Menurut Adam Smth, salah satu asas dalam pemungutan pajak adalah Asas Equality (asas keseimbangan dengan kemampuan atau asas keadilan): Pemungutan pajak yang dilakukan oleh negara harus sesuai dengan kemampuan dan penghasilan wajib pajak. Negara tidak boleh bertindak diskriminatif terhadap wajib pajak. Pemungutan pajak diukur dengan melihat perbandingan antara jumlah pajak yang dibayar dan kemampuan membayar (abiity to pay) pajak yang diukur dengan tingkat penghasilan wajib pajak. Tarif pajak disesuaikan dengan tingkat penghasilan penduduk berdasarkan kelompok penghasilan. (Suparmoko,2000:348). Kuantifikasi asas keadilan tersebut, dituangkan dalam formula matematis oleh Sigit Haryadi (2017) dalam persamaan tarif pajak yang berkeadilan yaitu :

1 Populaton Tax Target Income Share

Tax Rate $_{i} \%=100 \% x$ Fairness

Dimana:

$\overline{x \text { Employment } x}$

GNP $\quad x(N$

Income $^{2} S$ are $_{i} i=1$

Tax Rate $(\%)=$ Tarif pajak penghasilan untuk masing-masing kelompok pendapatan penduduk

Fairness $=$ Tingkat keadilan tarif pajak yang menunjukan persentase jumlah penduduk yang membayar pajak penghasilan dengan benar

Population $=$ Jumlah penduduk total

Tax Target $=$ sasaran pendapatan negara dari pajak penghasilan

GNP $=$ Gross National Product

$\mathrm{N}$ = banyaknya pengelompokan tarf pajak penghasilan

Income Share $=$ (pendapatan rata-rata penduduk pada suatu kelompok pendapatan) dibagi dengan (pendapatan rata-rata nasional dikalikan dengan N). $\sum$ Income share kuadrat $=$ jumlah dari kuadrat dari masing-masing income share

Berdasarkan formula diatas, diperoleh postulat :

a).Besar-kecilnya tarif pajak ditentukan oleh rasio pajak yaitu perbandingan antara target pendapatan negara yang diperoleh dari pajak penghasilan dibagi dengan pendapatan penduduk total. Makin besar rasio pjak, maka tarif pajak akan makin tinggi, dan sebaliknya.

b) Fairness atau tingkat keadilan tarif pajak, nilainya berkisar antara 0-100\%.

\section{Contoh Perhitungan}

1). Diketahui: Fairness $=100 \%$ (semua penduduk membayar pajak dengan benar). Population/employment $=2$; Tax target $/ \mathrm{GNP}=7 \% ; \mathrm{N}=4$; Income Share kelompok pajak $1=7 \%$; Income Share kelompok pajak $2=20 \%$; Income Share kelompok pajak 3 $=33 \%$; dan Income Share kelompok pajak $4=40 \%$; 
Maka: Tarif pajak untuk kelompok pertama $=100 \% \times(1 / 1) \times 2 \times 0,07 \times\{0,07:(0.07$ kuadrat +0.2 kuadrat +0.33 kuadrat +0.4 kuadrat $)\}=3,1 \%$; Tarif pajak untuk kelompok kedua $=100 \% \times(1 / 1) \times 2 \times 0,07 \times\{0,2:(0.07$ kuadrat +0.2 kuadrat +0.33 kuadrat +0.4 kuadrat) $\}=8,9 \%$; Tarif pajak untuk kelompok ketiga $=100 \% \times(1 / 1) \times 2 \times 0.07 \times\{0,33$ : (0.07 kuadrat +0.2 kuadrat +0.33 kuadrat +0.4 kuadrat $)\}=14,7 \%$; dan Tarif pajak untuk kelompok keempat $=100 \% \times(1 / 1) \times 2 \times 0.07 \times\{0,4:(0.07$ kuadrat +0.2 kuadrat +0.33 kuadrat +0.4 kuadrat) $\}=17,8 \%$.

Jadi saat semua penduduk telah membayar pajak dengan benar, maka tarif pajak penghasilan untuk 4 kelompok pendapatan adalah 3,1 \%; 8,9\%; 14,7 \%; dam 17,7 \%.

2). Fairness $=60 \%$, data lain sama dengan contoh 1 , maka didapat hasil perhitungan tarif pajak untuk 4 kelompok pendapatan adalah $=5,2 \% ; 14,9 \% ; 24,5 \%$; dan 29,7 \%., sangat mendekati tarif pajak penghasilan (PPh pasal 21) saat ini, yaitu $5 \% ; 15 \% ; 25 \%$ dan 30 $\%$. Ini berarti, fairness atau tingkat keadian tarif pajak di Indonesia adalah mendekati 60 $\%$, atau hanya $60 \%$ penduduk telah membayar pajak dengan benar. Akibatnya, penduduk yang telah membayar pajak dengan benar harus memikul beban pajak lebih tinggi.

(Bandingkan dengan contoh 1, saat Fairness $=100 \%$ )

\section{Kesimpulan}

Penetapan tarif pajak penghasilan dengan menggunakan formula "Tarif Pajak Berkeadilan" akan menghasilkan tarif pajak yang "adil" bagi setiap kelompok pendapatan. Apabila target pendapatan dari pajak berubah, besaran tarif pajak keadilan bisa disesuaikan secara fleksibel dan tetap adil bagi setiap kelompok pendapatan..Besaran tarif pajak berkeadilan untuk setiap kelompok pendapatan juga dipengaruhi oleh Fairness atau tingkat keadilan tarif pajak yang menunjukkan persentase jumlah penduduk yang membayar pajak penghasilan dengan benar. Semakin tinggi Fairness, tarif pajak berkeadilan untuk tiap tingkat pendapatan akan semakin turun.

\section{Daftar pustaka}

[1] Kementerian Keuangan Indonesia, Direktorat Jenderal Pajak. (2013). UndangUndang PPh dan Peraturan Pelaksanaannya.

[2] Lincolin Arsyad. (2010). Ekonomi Pembangunan. Edisi 5. Penerbit UPP STIM YKPN Yogyakarta.

[3] Michael P Todaro. (2004). Pembangunan Ekonomi di Dunia Ketiga. Edisi Kedelapan. Penerbit Erlangga, Jakarta. ISBN : 979-688-995-1

[4] M.Suparmoko. (1997). Keuangan Negara Dalam Teori dan Praktek. BPFE. Yogyakarta

[5] M.Suparmoko. (2000). Pokok-Pokok Ekonomika. BPFE Yogyakarta

[6] Sigit Haryadi. (2017). The Fairness over Inequality Index: Unfairness is Disaster - a notebook of Sigit Haryadi. Researchgate. DOI: 10.13140/RG.2.2.34379.4944907/2017.

[7] Samuelson dan Nordhaus. (2004). Ilmu Makroekonomi. Edisi Tujuh Belas. Penerbit PT Media Global Edukasi. ISBN 979-97855-8-8

[8] https://abdrah.wordpress.com/2015/07/05/pajak-pasal-pasal-pentingdalamundangundang-pajak-penghasilan/ 